\title{
Obituaries
}

\section{Professor Hugh Lionel Freeman}

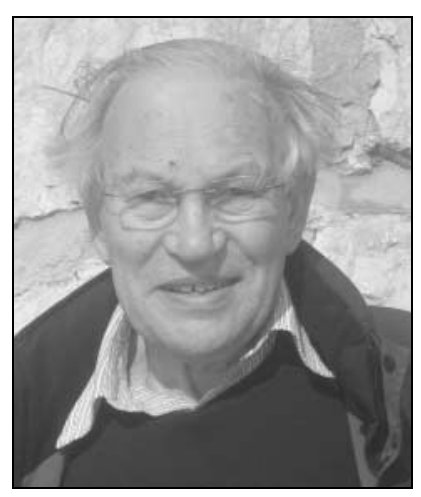

\section{Formerly Editor of the British Journal of Psychiatry (1983-1993)}

The simplest people are often the most complex. Hugh Freeman, who died aged 81 in May, 2011, was one of them. On the surface, he was a local boy from Salford made good by steady advancement from Altrincham Grammar School to a scholarship at Oxford University, and from there to become a Captain at the Royal Army Medical Corps, then completing his psychiatric training at the Maudsley Hospital to return to Salford in triumph as a consultant psychiatrist heading up a vibrant service. But Hugh had hardly started his career at this point. Salford was the launching pad for a multifaceted future involving consultancy to the World Health Organization, the initiation of one of the first comprehensive data registers in the UK (at Salford), editorship of the British Journal of Psychiatry, acting as the founding editor of Current Opinion in Psychiatry, Honorary Visiting Fellowship of Green College, Oxford, being awarded the Anniversary Medal of Merit at Charles University, Prague, Honorary Professorship at the University of Salford (which became a full university in 1967), and Honorary Fellowship of the Royal College of Psychiatrists.

But this does not explain Hugh adequately. With these accolades he was clearly a figure of worth and a member of the establishment, the curious concept of respectability that shows you have made it in society. He did not seem that way to me. At academic meetings it was Hugh who bluntly asked the questions that the ordinary hard-working psychiatrist might ask: 'What evidence have you that this would work in practice outside a teaching hospital?', 'Do you really expect that a busy psychiatrist would have the resources to do what you are recommending?', and, more simply - in despair - 'Are you in the real world?' He might have appeared a curmudgeon in such settings, but he was not. Hugh had a very good knowledge of history - his Oxford scholarship was in this subject - and this not only made him a natural editor of books about the history of psychiatry but also helped him to take the long view when it came to the current practice. He was fully aware of the implications of the concept of community psychiatry and the need for any advances to be made across the range of service settings. As he wrote more than 40 years ago, 'Community psychiatry is not just extramural work or a means of avoiding hospitalisation. A community mental health service is a comprehensive psychiatric service of care and treatment for a defined population, including full hospital facilities'. It was this abiding interest of a comprehensive service that led him to establish the Salford Psychiatric Case Register, a magnificent exemplar of the value of the genre, and to show, for example, that when the closing of mental institutions was in full swing, the care of the most severely ill was still predominantly based with hospital services, not with community ones.

Hugh was Editor of the British Journal of Psychiatry from 1983 to 1993. During that time he made many changes that have ensured the stability and long-term success of the Journal. These included the appointment of a fully professional staff, stimulating the Gaskell book series, with 40 volumes published during his editorship, the development of an accurate audit of all aspects of publications, and the establishment of the Publications Management Board, which has secured the financial stability of this part of the College's activities. Some of the changes have not been attained easily; Hugh introduced supplements to the Journal and some of these have been a valuable source of income to the College, but this was only achieved against a certain amount of opposition. On occasions such as these Hugh always stuck to his guns. If his mind was set on an aim he would see it not as an aspiration but as a clear destination that not only could, but definitely would be achieved, and he was seldom proved wrong. His strong sense of purpose was accompanied by his quiet demeanour. I never heard him raise his voice even when faced with vociferous antipathy. He could also be remarkably kind and thoughtful towards colleagues and staff, and this surprised many as superficially he often appeared to be detached.

My personal explanation of Hugh's complexity, at least in professional terms, is Salford. Salford does not have a good reputation. For many years its main association was with the popular song, Dirty Old Town. The tightly packed houses (8 square miles were covered by the Salford Register) were not noted for elegance or splendour, and when reading accounts of the Register's findings I often seemed to hear in the background the words of the song dragging me down the narrow alleys:

Found my love by the gaswork croft,

Dreamed a dream by the old canal,

Kissed my girl by the factory wall,

Dirty old town, dirty old town.

I feel for Salford personally. We Tyrers all come from Wigan, like Salford a dormitory town for Greater Manchester, and for years it too, ever since Orwell's The Road to Wigan Pier was published in 1938, has tried to escape the epithet of 'dirty old town'. But it has been more successful than Salford in getting some semblance of national respectability, probably helped a little by the performance of its very upright football team. Salford, even its sound hinting at disillusion, has struggled less effectively to create a new image. So in many ways I saw Hugh as standing up for all the lost and forgotten Salfords of this world. If you satisfied the requirement, 'Do unto Salford what you would do unto others' he would approve, but not until you had firmly convinced him it was not just flannel. And it was when you approached him on this level that you saw the real Hugh Freeman. I first encountered this when I was trying to get hold of a book I first read as a medical student, Trends in Mental Health Service by Freeman \& Farndale. I managed to find a copy, quite by chance, in a second-hand bookshop in Paris, and 
when I next saw Hugh I waved it in front of him and explained its background. The rest of his face became secondary to a broad smile. 'And were you at all disappointed on reading it again?', he asked merrily. 'Not at all, the message is still right, 40 years later', I responded. And it was.

Hugh was blessed with a happy marriage to Joan Casket (Freeman), well known as a professor of psychology who has recently received a Lifetime Achievement Award from the British Psychological Society for her work with gifted children. In their 54 years together they constantly encouraged and supported each other's work. She and their three sons, Stephen, Justin and Felix, a daughter, Rachel, and two grandsons, survive him.

Peter Tyrer

doi: 10.1192/pb.bp.111.036897

\section{Seymour Jamie Gerald Spencer KSG}

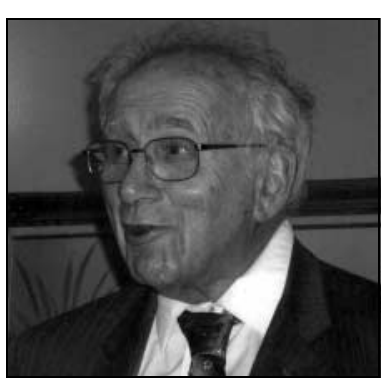

\section{Formerly Consultant Psychiatrist, Warneford Hospital Oxford and Clinical Lecturer, University of Oxford}

Seymour Spencer, although a general psychiatrist, had special interests in the care

of young people and the relation between psychiatry and religion. He was born a Jew and died a papal knight.

Seymour was born on 4 May 1920 into a successful Jewish family, the Schlesingers. His father was a banker and his mother came from a family of prominent industrialists. His great uncle had been the governor of Hong Kong and later of Queensland. Seymour was a gifted pupil and won a scholarship to Winchester where he was third on the Roll. In 1938, he went up to Oxford to read medicine and it was in the following year, after the declaration of war, that Seymour changed his surname to Spencer. He qualified in 1943, and in the same year met a monk from Ampleforth Abbey who so impressed him that he decided to convert to Catholicism.

Seymour Spencer's first training post was in gynaecology with Professor Chasser Moir in Oxford, his second was in general medicine with Sir William Hume in Newcastle. He then served in the Royal Army Medical Corps, mainly in India, until 1947. After demobilisation Spencer returned to Oxford, this time to train in psychiatry at the Warneford Hospital. He obtained the DPM (then the standard qualification in psychiatry) in 1951 and stayed in Oxford for a further 3 years while he successfully completed a doctoral thesis on student health. From Oxford, Spencer moved back to Newcastle as first assistant to Professor (later Sir Martin) Roth before taking a consultant post in Exeter. He and his growing family were happy in Exeter but when a consultant post became vacant at the Warneford Hospital, Spencer returned to Oxford where he was to spend the rest of his life.
In Oxford, Spencer worked as a general psychiatrist while developing his interest in the emotional problems of young people. He got on well with the young who warmed to his outgoing personality, his enthusiasm, his eccentricities, and his liking for puns and jokes. At the same time, he had natural empathy with young people, with an understanding of their points of view and their problems. Working with the clinical psychologist May Davidson, he helped to develop services for undergraduates at a time when there were no student counselling services. Together with others, they persuaded the university authorities to allow mentally ill students to take their examinations while in hospital, thereby safeguarding the future careers of many talented young people. During this time, Spencer became advisor to a nearby school for maladjusted children, and psychiatric advisor to a leading public school. Later in his career, he took charge of the service for adolescents during a period of reorganisation, and after retirement he worked with people who had intellectual disability. His natural warmth, energy, caring nature and broad clinical experience led to success in each of these roles.

Seymour Spence enjoyed court work and was often called as an expert witness. One barrister described how, in evidence in chief, it was often uncertain what Spencer might say next, but how in cross-examination he was devastating, responding to silks as though they were earnest but not very well-informed medical students. When attending a lecture, he had the habit of closing his eyes so as to concentrate better, thus appearing to be deeply asleep. In the subsequent discussion he would often take the speaker by surprise by asking a penetrating question that showed that he had heard and considered his every word.

Seymour was a devout Catholic and he was deeply concerned with the relationship between psychiatry and religion. His book, The Good that I Would, was part of a series on Christian education. It contains an overview of psychiatric and personality disorders, written for laymen, with comments on the way in which these disorders can impede moral responsibility. His work on the interface of psychiatry and religion, which continued throughout his career, was recognised when he became a Knight of the Order of St Gregory. His 90 th birthday was celebrated by a mass attended by a large congregation including both the Catholic Archbishop of Westminster and the Archbishop of Canterbury. This was one of four gatherings to celebrate his birthday: there can have been few other 90 year olds who had so many living friends - further evidence of Seymour's lifelong capacity to relate to people younger than himself.

Seymour Spencer married Margaret Behn in 1944 while he was still a houseman. She died in 1999 after 55 years of exceptionally happy marriage. They had five children who, together with his many friends and his strong faith, supported him in the last 12 years of his life. He had nine grandchildren, and one great-grandchild, whose birth gave him great satisfaction in the weeks before his death in May 2011 at the age of 91.

Michael Gelder

doi: 10.1192/pb.bp.111.036905 